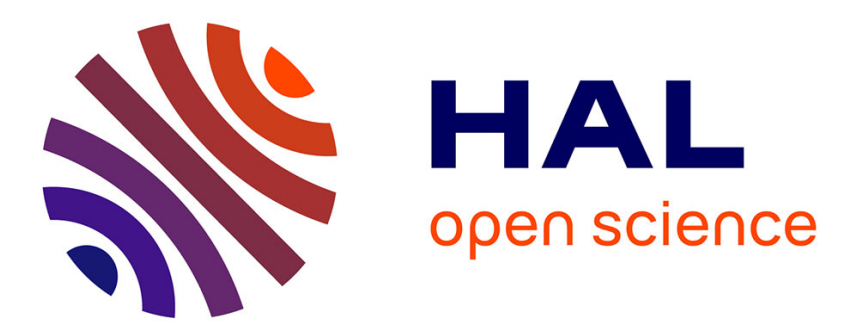

\title{
Spatial distribution of orchid bees in a rainforest/rubber agro-forest mosaic: habitat use or connectivity
}

Mauro Ramalho, Jaqueline Rosa, Marilia Dantas E Silva, Maise Silva, Daniela Monteiro

\section{- To cite this version:}

Mauro Ramalho, Jaqueline Rosa, Marilia Dantas E Silva, Maise Silva, Daniela Monteiro. Spatial distribution of orchid bees in a rainforest/rubber agro-forest mosaic: habitat use or connectivity. Apidologie, 2013, 44 (4), pp.385-403. 10.1007/s13592-012-0189-y · hal-01201308

\section{HAL Id: hal-01201308 \\ https://hal.science/hal-01201308}

Submitted on 17 Sep 2015

HAL is a multi-disciplinary open access archive for the deposit and dissemination of scientific research documents, whether they are published or not. The documents may come from teaching and research institutions in France or abroad, or from public or private research centers.
L'archive ouverte pluridisciplinaire HAL, est destinée au dépôt et à la diffusion de documents scientifiques de niveau recherche, publiés ou non, émanant des établissements d'enseignement et de recherche français ou étrangers, des laboratoires publics ou privés. 


\title{
Spatial distribution of orchid bees in a rainforest/rubber agro-forest mosaic: habitat use or connectivity
}

\author{
Mauro Ramalho ${ }^{1}$, Jaqueline Figuerêdo Rosa ${ }^{1,2}$, Marilia Dantas E Silva ${ }^{1}$, \\ Maise SILvA ${ }^{1}$, Daniela MonTEIRo ${ }^{1}$ \\ ${ }^{1}$ Laboratório de Ecologia da Polinização-ECOPOL, Instituto de Biologia-Universidade Federal da Bahia, Campus \\ Universitário de Ondina, Rua Barão do Jeremoabo s/n-Ondina, CEP- 40170-115, Salvador, Bahia, Brazil \\ ${ }^{2}$ Instituto Federal de Educação, Ciência e Tecnologia Baiano, Campus Guanambi, Distrito de Ceraíma, CP 09, CEP \\ 46430-000, Guanambi, BA, Brazil
}

Received 20 July 2012 - Revised 25 November 2012 - Accepted 19 December 2012

\begin{abstract}
The spatial distribution of orchid bees was analyzed in a mosaic of tropical rainforest and rubber tree groves in the Atlantic coast of Brazil (ARRF), comparing abundances and species compositions between replicas of the following landscape elements: small and large forest fragments, and rubber tree groves. Species compositions responded to all of the factors examined (time, mosaic elements, and distances; $P<0.009$ ). In contrast, total orchid bee abundance varied significantly only over time $(P=0.0001)$, but not among the different mosaic elements $(P=0.05)$. Fragment size and distances between the fragments have affected species composition and abundance of some few common species. Most local species were present in the rubber plantation, and several species were using this matrix as a source of odor. The seasonal quality shifting of this matrix (leaf fall) has had less influence on the spatial distribution of orchid bees than the distances between forest fragments and fragment sizes. Previous studies of forest fragmentation have shown very weak effects of matrix isolation in mosaics with 5 to $90 \%$ of forest cover, which supports the generalized expectation that organisms with well-developed dispersal capacities can respond to much higher thresholds of forest fragmentation.
\end{abstract}

habitat quality / fragmentation threshold / landscape context

\section{INTRODUCTION}

Habitat fragmentation can put species diversity at risk due to direct losses of area, expansion of anthropogenic matrices, and alterations of mobility (ecological connectivity) which together will affect regulatory populations processes and the spatial stabilities of coexisting communities in a landscape (Hanski 1999, Taylor et al. 2006; Schowalter 2006). Moreover, the associated ecological processes are not necessarily expressed in linear manners,

Corresponding author: M. Ramalho, mrramauro@gmail.com Manuscript editor: David Tarpy and theoretical models and experiments have been designed to examine fragmentation threshold on the landscape connectivity (Andrén 1994; With and Crist 1995; Bascompte and Solé 1996; Fahrig 2001). Thresholds are dependent on species-specific traits and scales of spatial interaction with the heterogeneous landscape (e.g., With and Crist 1995). Therefore, the responses of species or species assemblages to fragmentation in a landscape of heterogeneous habitats have a pre- and a post-threshold phases. In the pre-threshold phase, the change in relative area of habitat types should affect species or species groups depending on their specialization or habitat preferences (e.g., Wiens 1976; Pulliam and Danielson 1991). In the post- 
threshold phase, however, the rules of using habitat types and persistence in the landscape scale will depend on species response to spatial scale of fragmentation and tolerance to spreading anthropogenic matrices (and often mobility through it).

Some empirical studies examining the responses of Euglossini bees to tropical forest fragmentation have already been undertaken. Most of them have noted contrasting variations in abundance, richness or diversity with fragment size, distances, and edge effects (Powell and Powell 1987; Becker et al. 1991; Peruquetti et al. 1999; Brosi 2009; Nemésio and Silveira 2006, 2010; Aguiar and Gaglianone 2012). Males of several forest dwellers are known to move among forest fragments (e.g., Tonhasca et al. 2003; Brosi 2009; Nemésio and Silveira 2010), although few studies have directly measured their mobility through different matrices types (Raw 1989; Tonhasca et al. 2003; Milet-Pinheiro and Schlindwein 2005).

Roubik and Hanson (2004) assumed that the distributions and abundances of Euglossini bees that live in forests are influenced by physical factors and by the availability of nesting substrates. Considering the essential role of aromatic compounds in the reproductive activities of the males (ex. Dodson et al. 1969; Dressler 1982; Williams and Whitten 1983), the availability of these essences will count among the most relevant ecological variables in determining habitat quality and its use by these bees. However, there is not yet sufficient empirical data to draw conclusions about the influence of aromatic compounds on spatial distributions of orchid bee species (e.g., Eltz et al. 2005).

Species with well-developed capacities for dispersal should respond to a much higher threshold of habitat fragmentation (Andrén 1994; With and Crist 1995). That is, abrupt reductions in population size and in diversity of such species in response to habitat fragmentation will most likely occur with very high levels of habitat cover loss in the scale of local mosaics. Euglossini bees can fly very long distances, and their flight metabolic efficiency is considered quite extraordinary (e.g., Janzen
1971; Dudley 1995). Foraging flights over several kilometers are quite common, and experimental investigations have confirmed their ability to cover large distances in a single flight (Janzen 1971; Williams and Dodson 1972; Dressler 1982; Ackerman and Montalvo 1985). They are often considered "trapline pollinators" (Janzen 1971; Ackerman et al. 1982; Williams and Thomson 1998) because of their assumed high capacity for spatial orientation and memorization of long flight routes necessary for foraging sparse resources (such as orchid flowers) at low densities in tropical forests.

Regardless of dispersal ability, mobility of orchid bees through fragmented landscapes can be influenced by the type of matrix. It is expected that matrices with vegetation structures more similar to the habitats of the focal organisms would be more permeable than matrices with more divergent structures (Gascon et al. 1999). From the point of view of orchid bees that live in forests, the ability to use or move through non-arboreal matrices (pastures, sugarcane crops, etc.) should be less common than ability to use or move through arboreal or forested matrices (rubber tree groves, eucalyptus plantations, etc.).

Some previous studies have measured the occupation of forest fragments by orchid bees in the midst urban areas, pasturelands, annual monocultures, or secondary open vegetation (Powell and Powell 1987; Raw 1989; Becker et al. 1991; Peruquetti et al. 1999; Tonhasca et al. 2003; Nemésio and Silveira 2006, 2010; Brosi 2009; Aguiar and Gaglianone 2012). Here, we analyze the spatial distribution of orchid bees in a mosaic with arboreal matrix of rubber tree groves and tropical rainforest fragments. The general premises of this study were: (1) vegetation type is a factor that integrates relevant attributes (structure, microclimate, resources, etc.) of each habitat type, and the native tropical forest fragments are presumed to represent a habitat of greater general quality than extensive areas of rubber tree grove (matrix) to the focal group; (2) the relative proportion of vegetation cover of each habitat type in the mosaic and the distances between forest fragments may influ- 
ence the spatial variation in abundances of the orchid bees; (3) due to high flight range and so high dispersal ability, the observed spatial variation of these bees may be related to differential use of habitat types according to their quality (e.g., Wiens 1976; Holt 1993), or to alterations of ecological connectivity in landscape scale (e.g., Taylor et al. 2006) or both, depending on species-specific traits.

Direct sampling in matrices with odor baits will hardly discriminate between habitat use and connectivity, even in a highly fragmented landscape, in the absence of direct measures of orchid bees' mobility. Although the present study has this basic technical constraint, it progresses in the attempt to qualify the occupation of arboreal matrix by orchid bees, with a brief comparative synthesis of previous studies on their responses to forest fragmentation under different non-arboreal matrices (references above).

We sought to determine if the spatial distributions of orchid bees reflect spatial variations in habitat quality (Wiens 1976; Pulliam 1989; Pulliam and Danielson 1991), especially in terms of the rubber tree matrix and the tropical forest habitat. Adopting the premise that orchid flowers furnish critical odor resources for Euglossini bees in tropical forests (Dressler 1982; Ackerman 1983; Ramirez et al. 2002), it was also hypothesized that the relative quality of the rubber tree matrix might be inferred by comparing the spatial distributions of male bees bearing attached orchid pollinarium. Additionally, given that rubber trees (Hevea brasiliensis) lose their leaves seasonally, spatial-temporal variations in species composition and abundances might be expected if matrix quality per se was important for explaining spatial distributions at current level of forest fragmentation. The experimental assumptions were that: (a) spatial variations in the abundance of orchid bees should be interpreted as responses to spatial variations in habitat quality; and (b) if there are effects of forest fragment size on species compositions and abundances, then some isolating effect of the rubber matrix on the flow of individuals among the mosaic elements must also be assumed.

\section{MATERIALS AND METHODS}

\subsection{Study area}

Rubber trees (H. brasiliensis Müll.Arg) were first planted in southern Bahia State, Brazil, in 1910 (Reis and Mello 1987), and in the study landscape in the 1950s. Today, southern Bahia State is one of the major areas of natural rubber production in Brazil, and rubber plantations represent approximately $25 \%$ of the regional agroforestry landscape, mostly multicropped with cacao, but also with other monocultures (K. Flesher, personal communication Michelin 2011).

The present study was conducted in the Atlantic Rainforest/rubber plantation mosaic (ARRF) of the Michelin Ecological Reserve (MER), within the Michelin rubber plantation (MRP) and surrounding properties, in Bahia State $\left(13^{\circ} 48^{\prime} \mathrm{S}, 39^{\circ} 10^{\prime} \mathrm{W}\right.$; Figure 1). The MRP occupies a total area of 3,096 ha, comprising approximately 2,000 ha of forest (divided into three major fragments), 400 ha of wetlands and riparian vegetation, and 600 ha of rubber tree groves. The annual regional rainfall is approximately $2,000 \mathrm{~mm}$, with no dry period, and average monthly temperatures vary between 21.7 and $30.8{ }^{\circ} \mathrm{C}$. The landscape is dominated by low hills varying in height from 92 to $383 \mathrm{~m}$ above sea level that were originally covered by Lowland Tropical Rainforest (Veloso et al. 1991).

About $40-45 \%$ of the land within a radius of $4,000 \mathrm{~m}$ from the center of the ARRF study area (Figure 1) is covered by rainforest (including riparian forests), 30-35 \% by rubber plantations, and 15$21 \%$ by small villages and roads. The riparian forests are generally narrow (10-30 m wide) and discontinuous, and are currently composed of pioneer vegetation in arrested states of succession, similar to those found in very small forest fragments $(<5$ ha $)$ embedded within rubber agroforestry sites.

The rubber trees were planted in lines with $3 \mathrm{~m}$ spacing, with $8 \mathrm{~m}$ between the lines, at a density of approximately 500 trees per hectare (Pereira et al. 1996). Mature rubber trees in the region usually have diameters at breast height (DBHs) $>16 \mathrm{~cm}$ and are generally not more than $12 \mathrm{~m}$ tall. These plantations have relatively continuous but thin canopies with no stratification, and temporary very rarefied understories of herbaceous or low-shrub $(<1 \mathrm{~m})$ vegetation. The rubber trees lose their leaves for about 2 months each year (especially in mid- 


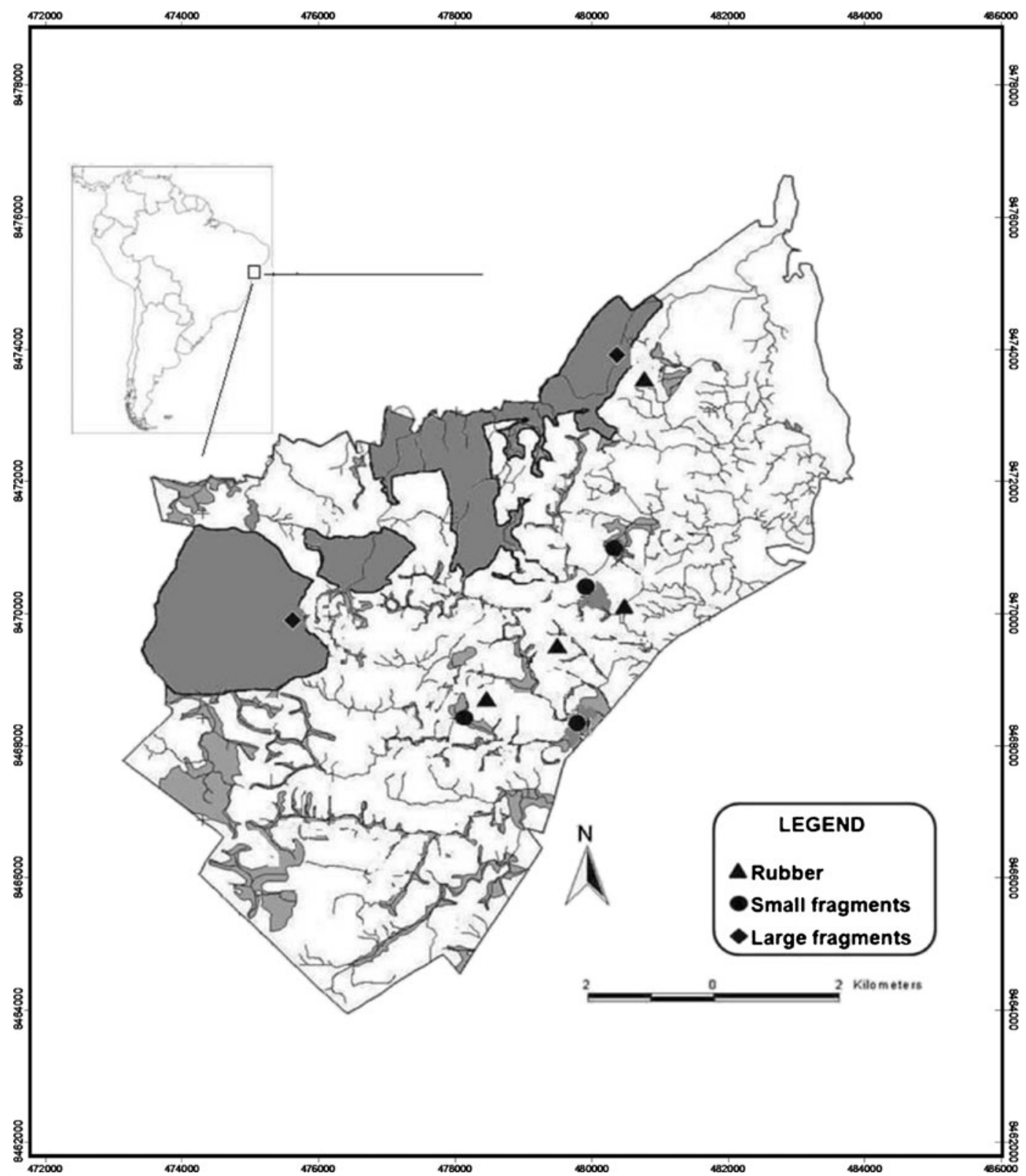

Figure 1. The Atlantic Rainforest/Rubber agro-Forest mosaic (ARRF) in eastern Tropical Brazilian coast (13 ${ }^{\circ}$ $48^{\prime} \mathrm{S} \times 39^{\circ} 10^{\prime} \mathrm{W}$ ). Atlantic rainforest (grey), rubber plantation + worker villages, and local roads (white). Symbols indicate the relative position of replicas.

June to mid-September), which alters the microclimatic conditions of this matrix (direct sunlight and so on). Tree densities in the surrounding tropical forest were estimated to be around 600 trees/ha with DBHs $>16 \mathrm{~cm}$, as measured at 30 random points in the "Pancada Grande" mature forest fragment using the T-square technique (see Sutherland 2006). Forest edges in the ARRF are often in direct contact with the rubber tree matrix. 


\subsection{Sampling design and constraints}

Three landscape elements (LE) were considered in the study area: "large forest fragments," "small forest fragments," and the "rubber matrix." The large forest fragments were represented by the two largest remnant forested areas in the MRP, locally known as the "Pancada Grande" (625 ha) and "Pacangê" forests $(550 \mathrm{ha})$, that are covered by secondary forest in various stages of succession, but with large remnant core areas of old-growth forest on the steepest slopes and ridges (Flesher 2006). The distance between the two largest fragments was $1,400 \mathrm{~m}$, with a smaller 140 ha forest fragment between them. The Pacangê forest is part of a continuous forest $(13,000 \mathrm{ha})$ that extends beyond the MER, while the "Pancada Grande" forest is isolated and surround by an agricultural matrix dominated by rubber tree groves. The four small forest fragments vary in size from 5 to 50 ha.

We used paired samples of Euglossini bees that have been captured simultaneously in all of the LE. The linear distances between the sampling points in the two largest fragments ranged from 1.8 to $7.4 \mathrm{~km}$ (Figure 1). The linear distances between the edges of the large and small forest fragments (interspersed within the rubber matrix) ranged from 1.5 to $3.6 \mathrm{~km}$.

The three landscape elements were represented by four sampling replicates each. Pairs of sampling points were installed $200 \mathrm{~m}$ distant one from the other in each LE in order to reduce interference. The two sites $200 \mathrm{~m}$ apart were treated as a single point (a replica). Two sampling points were placed $25 \mathrm{~m}$ from the forest edges in both the small and larger forest fragments, and two additional sampling points were placed $150 \mathrm{~m}$ from the forest edges in the largest forest fragments. The sampling points in the rubber matrix were placed at similar distances from small forest fragments but distant from the largest forest patches (Figure 1).

Three odor traps were used at each sampling point, each with a different aromatic compound. The traps were installed in the shade $1.5 \mathrm{~m}$ above ground level, and consisted of transparent plastic bottles with three lateral openings. Within them, suspended compact cotton balls (diameter $\sim 0.7 \mathrm{~mm}$ ) were baited by complete immersion in one of the following aromatic compounds: eucalyptol, methyl salicylate, or vanillin. These three aromatic baits are considered to have the widest attraction spectra (attracting the most species) among the 48 compounds commonly used in odor traps (Roubik and Hanson 2004), and previous studies in the region have proven them to be efficient (e.g., Peruquetti et al. 1999; Bezerra and Martins 2001). To reduce interference when large numbers of individuals are attracted to baits (e.g., Justino and Augusto 2010), all bees were removed from each trap at 1-h intervals, and the baited cotton balls were replenished with their corresponding essences.

The differential attractions of species by different aromatic compounds are potential sources of skewed sampling with odor baits, especially as related to measures of apparent rarity (e.g., Mattozo et al. 2011); therefore, a rare species among the samples may not necessarily be rare within a mosaic. Attractiveness of odor baits may also be influenced by seasonal variation in fragrance choice (Ackerman 1989) and stochastic factors (Tonhasca et al. 2002; Nemésio and Silveira 2010). Finally, observed differences in species abundance between areas within the same habitat could be caused by random sampling effects associated with large samples (e.g., large numbers of individuals attracted to odor baits) (Armbruster 1993; Tonhasca et al. 2002). On the other hand, despite orchid bees showed speciesspecific preferences for certain chemicals, the "floral scents of euglossophilous flowers are normaly chemical mixtures," and the fragrance phenotypes found in Euglossa "are clearly assembled from several to many" odor sources (e.g., Eltz et al. 2005). Therefore, each species collects various compounds and not just those considered "preferred" in order to compose species-specific scent cocktails. Moreover, comparative methodological analyses have indicated that sampling regimes using aromatic compounds could generate satisfactory results in terms of evaluating local distributions and abundances of orchid bees (Roubik 2001; Brosi 2009).

In the strict context of comparative analyses of spatial distributions within local mosaics as considered here, skewed censuses of orchid bees were minimized by using wide-spectrum odor baits and by employing adequate numbers of replicas with simultaneous and paired samples throughout the year. Species with less than $1 \%$ occurrence in the present 
study were referred to as rare in the total sample, even though these estimates could be skewed in exceptional cases of highly specialized aromatic attractiveness (Becker et al. 1991; Roubik and Hanson 2004; Eltz et al. 2005; Mattozo et al. 2011). These "rarely sampled species" are also assumed to have small local populations because of their (assumed) more specialized requirements.

In the absence of direct measures of mobility through a local mosaic or landscape (e.g., markrecapture results), the presumed high mobility of orchid bees also imposes intrinsic restrictions on data interpretation. First, we assumed that the spatial variation in abundance of orchid bees could be interpreted as a response to the spatial variation in habitat quality within a mosaic. Second, if there are effects of fragment sizes on species composition and abundance, we should sustain some isolation effect of the matrix on the bees' mobility between the elements of the mosaic. Third, we have not made an experimental measure of fragmentation threshold, but we approach this issue by comparing the responses of different species in the same mosaic (ARRF) and, also, by comparing previous raw data, proposing a simple standardized qualitative measure of orchid bees' response to fragmentation (species not affected by fragmentation; see Table V).

The neutral term "occupation" was used in the present study when it was not possible to differentiate between habitat use (e.g., visiting odor sources) and mobility (ecological connectivity) through rubber tree grove. The terms "mosaic" and "landscape" were used synonymously, based on the presumption that both concepts involve heterogeneous habitats at spatial scales perceptible to the group of interestwhich is essentially equivalent to the definition proposed by Turner et al. (2003): "landscape is an area that is spatially heterogeneous in at least one factor of interest." The term "matrix" refers to nonforested and disturbed habitats, and it was used regardless of their proportional extension in each mosaic.

\subsection{Sampled bees}

Male orchid bees were sampled over 3 days/month and 21 days during a 7-month period in 2006 (March, April, June, August, September, October, and De- cember; some months were excluded from the analysis due to flaws in the paired simultaneous samples in all replicas). In any case, the sampled months span normal variation in temperature and rainfall throughout the year and periods of high (October to March) and low flight activity (JulySeptember) of orchid bees in the region (e.g., Rosa et al. 2008). Samples were collected between 0800 and 0200 hours on each sampling day. This is the main daily period of activity of orchid bees in the region (e.g., Melo et al. 2009), and few individuals and no other species had been observed in a previous pilot study in the ARRF area during uninterrupted 24-h samplings (M. Ramalho personal communication).

The number of males captured in each landscape element with orchid pollinaria attached to their bodies was explored as an indirect measure of the relative quality of habitats in the ARRF. It was assumed that captured bees bearing pollinarium were more likely to have recently visited flowers within that habitat, as opposed to arriving from very long distances. All bees with complete pollinarium (or identifiable traces) were used in these analyses. Dr. Cássio van den Berg of the Bahia State University at Feira de Santana-UEFS collaborated in identifying the orchid pollinarium.

The bees were sacrificed with ethyl acetate, transferred to plastic bottles, and deposited in the Pollination Ecology Lab (ECOPOL) collection at the Federal University of Bahia-UFBA. The specimens were examined using a stereomicroscope and identified with the aid of published keys (Silveira et al. 2002; Roubik and Hanson 2004) and reference material from ECOPOL. Dr. André Nemésio (Federal University of Minas Gerais) and Dr. Ednaldo Luz das Neves (Jorge Amado Faculty-Salvador-Ba) collaborated in identifying the orchid bee species. "Abbreviations of the genus-rank nomina follow the current usage in orchid-bee studies": Eg. for Euglossa and El. for Eulaema (see Andrade-Silva et al. 2012).

\subsection{Statistical analyses}

Some emphasis was given to the analyses of the spatial variation of abundances (especially for the more common species within the mosaic) considering the robustness of the experimental design: the numbers of paired samples and replicates of land- 
scape elements, and the duration of the sampling period. Possible effects of large samples in detecting significant differences in abundances within a habitat are discussed in more detail by Tonhasca et al. (2002) and Armbruster (1993).

Non-parametric multivariate analyses of covariance (NPMANCOVA: Anderson 2001, 2005; McCune and Grace 2002) were used to evaluate: (1) changes in abundance and species compositions of orchid bees among the LE; and (2) the effects of distance from the nearest fragment and from the two largest fragments; (3) changes in abundance throughout the year and the interaction between time and LE. When the spatial variation was significant, it was done a second test to check how the variance was shared between the elements of the landscape (influence of the levels of factors). This analysis protocol used a sample size $(N)$ equal to four, with two orthogonal factors: (a) time, with seven levels of factors (the 7 months); and (b) LE, with three levels of factors (large fragments, small fragments, and the rubber matrix). NPMANCOVA was also used to measure the spatial distribution of orchid pollinaria attached to the male bees. The NPMANCOVA analyses were run with permutational multivariate analysis of variance software developed by Anderson (2005). The data were transformed by extracting the square root to: (1) reduce the differences between common and rarely sampled species and (2) improve the assumption of homogeneity of variances (homoscedasticity). No data standardization was performed, and the Bray-Curtis distance measure was used. The significance level adopted was 0.05 . The premise of normality was tested by the KolmogorovSmirnov test, using the Graphpad Instat 3.05 program. Homoscedasticity was evaluated by the Levene test for equality of variances, using SPSS 13.0 for Windows.

\section{RESULTS}

During 7 months of simultaneous paired sampling in the Atlantic rainforest and rubber plantation mosaic (ARRF), a total of 1,779 Euglossini bees were collected representing two genera: Euglossa Latreille, 1802 (1,295 individuals) and Eulaema Lepeletier, 1841 (484 individuals). The genus Exaerete Hoffmannsegg 1817 was excluded from this analysis because insufficient numbers of individuals were collected to be able to perform most of the statistical analyses. Three species were assigned as "rarely sampled species" (less than $1 \%$ of the total number of sampled bees), and they were also assumed to have small local populations (Table I; see also Section 2).

The time factor influenced species composition, total abundance, and the abundances of approximately $60 \%$ of the observed Euglossini species (Euglossa cordata, Euglossa ignita, Euglossa imperialis, Euglossa sapphirina, Eulaema atleticana, and Eulaema nigrita). In contrast, the LE and the spatial distances affected the species composition, although they did not explain the variations in total abundances of Euglossini (Table I).

The great majority of the species was not affected by distances between small and large fragments neither by LE. Only E. imperialis responded simultaneously to LE and the distances between fragments; and E. atleticana demonstrated significant variations in abundance only between LE.

Contrary to expectations, the interactions between the period $(\mathrm{T})$ of the year and the landscape elements (LE) did not result in variations in spatial distribution of bee species within the mosaic (Table I). The high observed temporal variations in species abundances therefore had no significant influence on spatial distributions within the mosaic. More importantly, temporal variations in matrix conditions of the rubber tree groves (leaf fall in mid-June to mid-September) likewise did not produce important changes in the spatial occupation of ARRF mosaic by the orchid bees.

All of the factors examined (time, distance, and landscape elements) influenced species compositions (Table I). In contrast, and with the exception of time, none of the other factors affected total abundance, and for this reason, the variations seen in species compositions are assumed to involve mainly "rarely sampled species" $(<1 \%)$. Therefore, variation in species compositions may be a sample artifact related to the random detection of species with small number of individuals in each landscape ele- 
Table I. The influence of factors (LFD, LE, and $T$ ) and the interactions of factors ( $T \times$ LE) on the spatial distribution of Euglossini bees in the ARRF mosaic: $L F D=$ distance of the small fragments from the nearest large fragment; $\mathrm{LE}=$ landscape elements (small and large forest fragments and the rubber matrix); $T=$ time period; $P$ probability (NPMANCOVA).

\begin{tabular}{|c|c|c|c|c|c|}
\hline Dependent variables & Species abundance & $\operatorname{LFD}(P)$ & $\operatorname{LE}(P)$ & $T(P)$ & $T \times \operatorname{LE}(P)$ \\
\hline Species compostition & & 0.0003 & 0.0090 & 0.0001 & 0.2819 \\
\hline Total abundance & & 0.7191 & 0.0541 & 0.0001 & 0.5824 \\
\hline $\begin{array}{l}\text { Euglossa (Glossura) iopoecila } \\
\text { Dressler } 1982\end{array}$ & 105 & 0.6889 & 0.3949 & 0.1714 & 0.1324 \\
\hline $\begin{array}{l}\text { Euglossa (Euglossa) cordata } \\
\text { Linnaeus, } 1758\end{array}$ & 112 & 0.8079 & 0.4565 & 0.0357 & 0.7537 \\
\hline $\begin{array}{l}\text { Euglossa (Glossura) ignita } \\
\text { Smith, } 1874\end{array}$ & 636 & 0.0481 & 0.8411 & 0.0399 & 0.4752 \\
\hline $\begin{array}{l}\text { Euglossa (Glossura) imperialis } \\
\text { Cockerell, } 1922\end{array}$ & 430 & 0.0003 & 0.0093 & 0.0010 & 0.2121 \\
\hline $\begin{array}{l}\text { Euglossa (Glossurella) sapphirina } \\
\text { Moure, } 1968\end{array}$ & $11^{\mathrm{a}}$ & 0.1920 & 0.8687 & 0.0087 & $0.0306^{\mathrm{c}}$ \\
\hline $\begin{array}{l}\text { Eulaema (Eulaema) bombiformis } \\
\text { Packard, } 1869\end{array}$ & 47 & 0.1048 & 0.2722 & 0.3283 & 0.2169 \\
\hline $\begin{array}{l}\text { Eulaema (Apeulaema) cingulata } \\
\text { Fabricius, } 1804\end{array}$ & $15^{\mathrm{a}}$ & 0.3529 & 0.8368 & 0.3375 & 0.0515 \\
\hline $\begin{array}{l}\text { Eulaema (Eulaema) atleticana } \\
\text { Nemésio } 2009\end{array}$ & 265 & 0.0649 & 0.0006 & 0.0057 & 0.3788 \\
\hline $\begin{array}{l}\text { Eulaema (Apeulaema) nigrita } \\
\text { Lepeletier, } 1841\end{array}$ & 157 & 0.6476 & 0.0587 & 0.0001 & 0.2577 \\
\hline $\begin{array}{l}\text { Euglossa (Euglossa) securigera } \\
\text { Dressler } 1982\end{array}$ & $07^{\mathrm{ab}}$ & & & & \\
\hline $\begin{array}{l}\text { Euglossa (Euglossa) mixta } \\
\text { Friese } 1899\end{array}$ & $01^{\mathrm{ab}}$ & & & & \\
\hline
\end{tabular}

\footnotetext{
${ }^{\text {a }}$ Rare species (see Section 2)

${ }^{\mathrm{b}}$ Species present and not included in this analysis

${ }^{\mathrm{c}}$ Significant value is an artifact due the large number of samples with zeros
}

ments or, alternatively, it might imply that the fragmentation threshold has been exceeded for a few species with small populations and greater fidelity to the more extensive forest habitat.

Species compositions were affected by habitat quality (rubber tree groves $\times$ forest) and forest fragment size (Table II). In the latter case, the spatial variation is significant only in relation to the largest forest remnants $(P=0.01)$. First of all, this latter result refutes the above argument that variation in species composition could be due to sampling artifacts of species with small populations in the mosaic. In contrast, the rarely sampled species persisted mainly in the better quality habitats within the largest areas (largest forest fragments) of the ARRF mosaic
(Figure 1). This also supports the previous argument that forest fragmentation threshold has been exceeded to a few species which likely is reacting in a negative manner to the spreading of rubber tree groves.

The total abundance of orchid bees was not affected by fragment size neither by habitat quality (forest $\times$ rubber tree groves; Table II). Concurrent and paired samples give some security to the detailed analysis of the spatial distribution of some species and their responses to the levels of factors (SF, LF, and RM). Only the common species with detected significant spatial variations in the landscape scale (Table I) were included in this second detailed analysis, i.e., E. imperialis, E. atleticana, and E. nigrita. 
Table II. The effects of the levels of factors (SF, LF, RM) on the spatial distribution of Euglossini bees in the ARRF mosaic.

\begin{tabular}{llll}
\hline Dependent variables & $\mathrm{SF} \times \mathrm{LF}(P)$ & $\mathrm{SF} \times \mathrm{RM}(P)$ & $\mathrm{LF} \times \mathrm{RM}(P)$ \\
\hline Species composition & 0.0118 & 0.0706 & 0.0118 \\
Total abundance & 0.0867 & 0.0574 & 0.0532 \\
Euglossa imperialis & 0.0001 & 0.0320 & 0.0232 \\
Eulaema atleticana & 0.0001 & 0.0118 & 0.0011 \\
Eulaema nigrita & 0.0001 & 0.0602 & 0.2701 \\
\hline
\end{tabular}

Only the three most abundant species with significant (or marginally significant) variations in their spatial distributions were included in this analysis

$S F$ small forest fragments, $L F$ large forest fragments, $R M$ rubber matrix, $P$ probability (NPMANCOVA)

The spatial variations of the first two species were significant with all levels of factors (Table II, Figure. 2), and so the fragment size and habitat quality (and the assumed poor quality of rubber tree groves) are negatively affecting the spatial distribution of those common species in the mosaic. The generalist species E. nigrita stood out in terms of its similar abundance in both habitat types and higher abundance in the small forest fragments $(P=0.0001)$. Likely, a subtle process of density compensation was starting to operate at spatial scale of the ARRF mosaic.

Out of the total number of Euglossini bees sampled, 116 individuals had orchid pollinaria (or their traces) adhering to their bodies, including 58 specimens of Euglossa with intact pollinia: E. ignita (39), E. cordata (08), Euglossa securigera (07), E. imperialis (03), and Euglossa mixta (01). The relationship between bee species and genera of orchids varied significantly ( $P=0.0001$; Table III). Euglossa species also influenced the abundance of pollinaria and, particularly, there was a predominant relationship between $E$. ignita with Catasetum flowers in the rubber tree grove (Tables III and IV). However, the spatial variation of orchid pollinaria was not significant among the LE neither considering coupled influence with species of Euglossa (LE $\times \mathrm{ES}$ ). The most significant differences in the relationship between bees and orchids involved $E$. ignita and E. cordata (Table IV). These two species presented important differences among themselves in their relationship with orchid genera and, particularly, with Catasetum flowers. This last difference should also explain most of the observed influence of bee species (ES) on spatial distribution of Catasetum among the landscape elements (Table III).

\section{DISCUSSION}

The relationship between ecological distribution (numbers of sites or habitat patches occupied) and abundance (D-A patterns) could be influenced by sampling artifacts that principally affect rare species (Hanski et al. 1993; Brown 1995). The D-A pattern is apparent in most of the studies of forest fragmentation with orchid bees (Table V) that presented rough data on species abundances (e.g., Peruquetti et al. 1999; Tonhasca et al. 2003; Milet-Pinheiro and Schlindwein 2005; Brosi 2009; Nemésio and Silveira 2010). For instance, when the rarely sampled species were excluded from the analyses, the proportions of species not affected by fragmentation (sppNF) converged on $100 \%$ thus demonstrating weak fragmentation effects on most of the common species of orchid bees.

"Rarely sampled species" in the ARRF mosaic (e.g., E. sapphirina and Eulaema cingulata) were assumed to have small local populations because they also must be more specialized in terms of their choices of odor sources and habitat use (see 

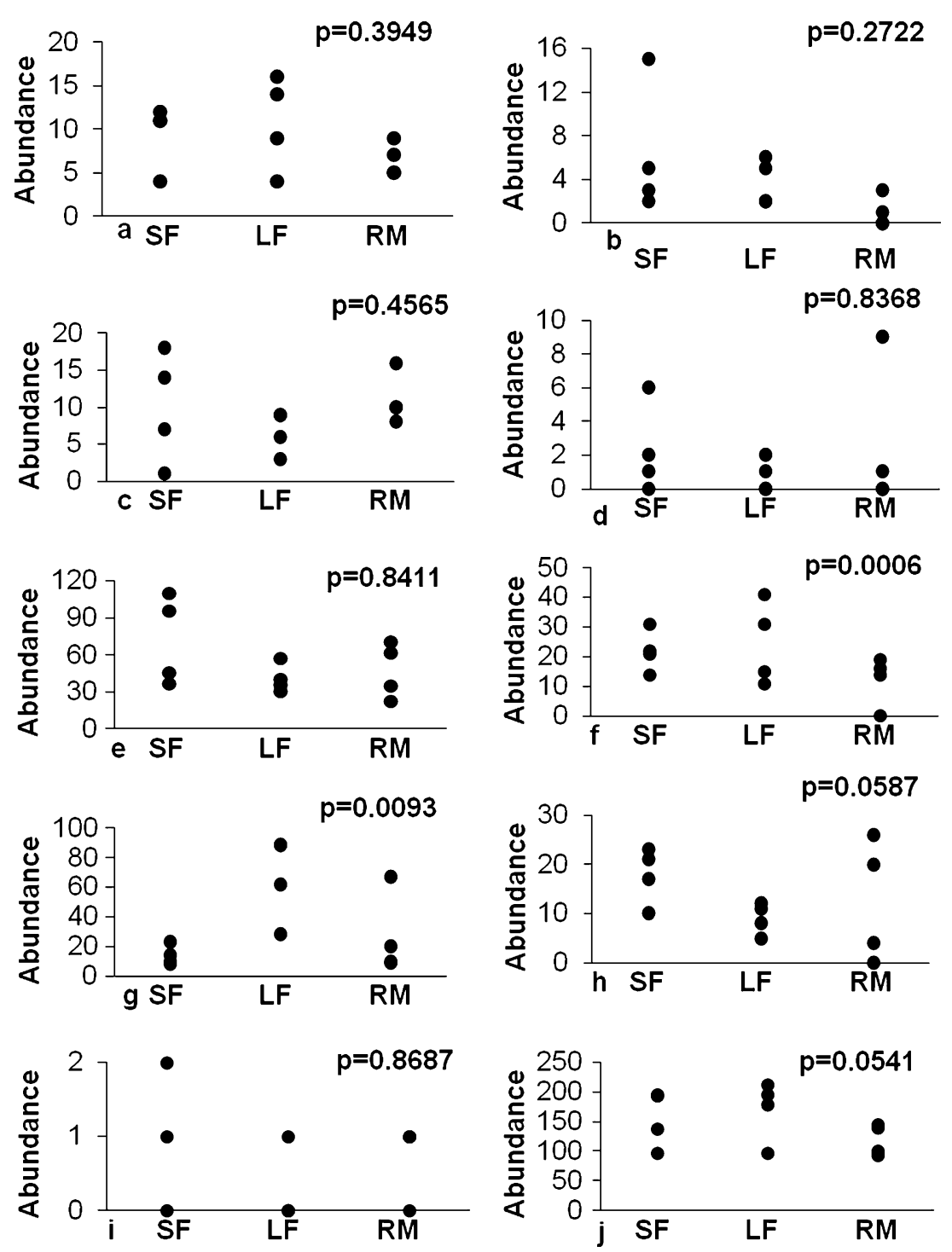

Figure 2. Spatial distributions of abundances of Euglossini species in the ARRF mosaic. Landscape elements: small forest fragments $(S F)$; large forest fragments $(L F)$, and rubber tree matrix $(R M)$. a $E$. iopoecila; b $E$. cordata; $\mathbf{c}$ E. ignita; $\mathbf{d}$ E. imperialis; e E. sapphirina; f E. bombiformis; $\mathbf{g}$ E. cingulata; h E. atleticana; $\mathbf{i} E$. nigrita; $\mathbf{j}$ Total abundance.

Section 2). If these "rare" species are disproportionately affected by habitat fragmentation (as was observed in Lepidoptera; Summerville and Crist 2001), it provides an explanation for the observed spatial variations of species compositions without any variation in the total abundances of orchid bees in the ARRF.
Spatial variations in the species composition were dissociated from spatial variations in total abundances, and therefore, they often were due to "rarely sampled species" (rsspp $<1 \%$ ) in the ARRF mosaic. Moreover, the variations were statistically significant mainly in relation to the largest forest remnants, which means that the 
Table III. The influence of Euglossa species (ES) and landscape elements (LE) on the spatial distribution of orchid pollinaria genera attached to male bees $(N=58)$ in the ARRF mosaic.

\begin{tabular}{lllc}
\hline Dependent variables & ES $(P)$ & LE $(P)$ & ES $\times$ LE $(P)$ \\
\hline Orchid genera & 0.0001 & 0.8133 & 0.4266 \\
Total abundance & 0.0002 & 0.6632 & 0.2692 \\
Gongora sp & 0.0145 & 0.4125 & 0.1191 \\
Coryanthes sp & 0.1020 & 0.8561 & 0.0794 \\
Catasetum sp & 0.0001 & 0.5772 & 0.4052 \\
\hline
\end{tabular}

Pollinaria traces were included in the analysis of total abundance of bees $(N=116)$.

$P$ probability (NPMANCOVA)

same "rsspp" are often absent from both small fragments and rubber tree groves. This spatial pattern of "rsspp" could be produced by two basic mechanisms: (a) reduced mobility of individuals from large source areas (e.g., Chesson 2000) with "larger populations" towards small forest fragments; (b) reduced residence time of male bees in small ( $<50$ ha) fragments, an expected response to very low local densities of females (of species with small populations at the mosaic scale). The second explanation is an Allee effect that has been shown to affect small-scale spatial population structure of butterflies during breeding period (e.g., Kuussaari et al. 1998), and it presupposes mobility of male orchid bees through the rubber tree matrix.

Contrasting to all previously studied mosaics with no sampled data for matrices, (Table V), direct measures of abundance in the rubber tree grove at the ARRF demonstrated that the most common Euglossini species occupy this matrix, including species known to be closely associated with Atlantic Forest habitats, such as $E$. imperialis and E. atleticana. It was expected that these two species, which are restricted to forests at greater spatial scales (e.g., Peruquetti et al. 1999; Faria and Melo 2007) would show significant dependence on forests at local scales. The abundances of both species have varied with respect to all of the ARRF landscape elements and probably to spatial variations in habitat quality (e.g., forest $\times$ rubber tree groves), and thus, they are responding to heterogeneity at the mosaic scale (e.g., Pulliam 1989; Pulliam and Danielson 1991). These two species also responded to forest fragment size; therefore, one

Table IV. Comparisons between Euglossini species for the presence of orchid pollinaria attached to the male bees $(N=58)$.

\begin{tabular}{llll}
\hline & Pollinaria abundance $(P)$ & Orchid genera composition $(P)$ & Catasetum $(P)$ \\
\hline E. ignita $\times$ E. cordata & 0.0277 & 0.0015 & 0.0005 \\
E. ignita $\times$ E. securigera & 0.0003 & 0.0003 & 0.0001 \\
E. ignita $\times$ E. imperialis & 0.0268 & 0.0267 & 0.0012 \\
E. securigera $\times$ E. cordata & 0.1066 & 0.1140 & 0.3310 \\
$E$. securigera $\times$ E. imperialis & 0.0667 & 0.0356 & 0.1552 \\
$E$. cordata $\times$ E. imperialis & 0.9955 & 0.1588 & 0.5579
\end{tabular}

Bee species represented by only one male (with intact pollinia) in samples were excluded from this analysis. Only orchid Catasetum presented a sufficient number of specimens $(N=39)$ to detailed statistical analysis

$P$ probability (NPMANCOVA) 
Table V. Studies of forest fragmentation effects on Euglossini bees in the Neotropics.

\begin{tabular}{|c|c|c|c|c|c|}
\hline $\begin{array}{l}\text { Tropical } \\
\text { forest type } \\
\text { and cover }\end{array}$ & $\begin{array}{l}\text { Fragment } \\
\text { numbers }{ }^{\mathrm{b}} \text {, size } \\
\text { and distances }^{\mathrm{c}}\end{array}$ & $\begin{array}{l}\text { Matrix type and } \\
\text { sampling }\end{array}$ & $\begin{array}{l}\text { Fragmentation } \\
\text { effects }^{\mathrm{d}}\end{array}$ & $\% \operatorname{SppNAF}^{\mathrm{e}}$ & References $^{f}$ \\
\hline $\begin{array}{l}\text { BARF } \\
<10 \%\end{array}$ & Few & $\begin{array}{l}\text { Urban area } \\
\text { NO }\end{array}$ & $\begin{array}{l}\text { Reduced mobiliyt }^{\mathrm{d}^{\mathrm{j}}} \\
\text { between forest } \\
\text { fragments. }\end{array}$ & n.a. & Raw 1989 \\
\hline $\begin{array}{l}\text { BARF } \\
<10 \%\end{array}$ & $\begin{array}{l}\text { Few } \\
16-190 \mathrm{ha} \\
1-6.0 \mathrm{~km}\end{array}$ & $\begin{array}{l}\text { Urban area } \\
\text { NO }\end{array}$ & $\begin{array}{l}\text { Reduced mobility } \\
\text { between forest } \\
\text { fragments. Effect } \\
\text { of fragment size } \\
\text { on diversity. } \\
\text { Higher diversity } \\
\text { in moderate size } \\
\text { fragments. }\end{array}$ & $80(\mathbf{8 6})$ & Peruquetti et al. 1999 \\
\hline $\begin{array}{l}\text { BARF } \\
<10 \%\end{array}$ & $\begin{array}{l}\text { Single isolated } \\
476 \text { ha }\end{array}$ & $\begin{array}{l}\text { Sugarcane } \\
\text { monoculture } \\
\text { YES }\end{array}$ & $\begin{array}{l}\text { Reduced mobility at } \\
\text { very short distances } \\
\text { through very } \\
\text { extensive matrix }\end{array}$ & 23 (n.a.) & $\begin{array}{l}\text { Milet-Pinheiro and } \\
\text { Schlindwein } 2005\end{array}$ \\
\hline $\begin{array}{l}\text { BARF } \\
<10 \%\end{array}$ & $\begin{array}{l}\text { Few } \\
10-3,500 \text { ha } \\
\text { n.a. }\end{array}$ & $\begin{array}{l}\text { Sugarcane, } \\
\text { pastures, urban } \\
\text { área } \\
\text { NO }\end{array}$ & $\begin{array}{l}\text { Effect of fragment } \\
\text { size on diversity. } \\
\text { Effect of distance on } \\
\text { similarity between } \\
\text { fragments. }\end{array}$ & $\begin{array}{l}84 \text { (n.a.) } \\
80 \text { (n.a.) } \\
75 \text { (n.a.) }\end{array}$ & Darrault et al. 2006 \\
\hline $\begin{array}{l}\text { BARF } \\
>20<30 \%\end{array}$ & $\begin{array}{l}\text { Few } \\
50 \text { ha } 0.36- \\
1.7 \mathrm{~km}\end{array}$ & $\begin{array}{l}\text { Pastures } \\
\text { NO }\end{array}$ & $\begin{array}{l}\text { Moderate mobility } \\
\text { between forest } \\
\text { fragments }\end{array}$ & n.a. & Tonhasca et al. 2003 \\
\hline $\begin{array}{l}\text { SF } \\
\qquad<10<30 \%\end{array}$ & $\begin{array}{l}\text { Many } \\
0.25-230 \text { ha } \\
1-2.0 \mathrm{~km}\end{array}$ & $\begin{array}{l}\text { Pastures } \\
\text { NO }\end{array}$ & $\begin{array}{l}\text { Effect of fragment } \\
\text { size on abundance. } \\
\text { Positive edge effect } \\
\text { on abundance and } \\
\text { diversity. No effect } \\
\text { of fragment } \\
\text { isolation on } \\
\text { diversity }\end{array}$ & $26(\mathbf{8 6})^{\mathrm{e}^{\prime}}$ & Brosi 2009 \\
\hline $\begin{array}{l}\text { TDO-SF } \\
<10<30 \%\end{array}$ & $\begin{array}{l}\text { Few } \\
\qquad 1-350 \text { ha n.a. }\end{array}$ & $\begin{array}{l}\text { Disturbed fields } \\
\text { and savannahs } \\
\text { and urban area } \\
\text { NO }\end{array}$ & $\begin{array}{l}\text { Effect of the core area } \\
\text { size of fragments on } \\
\text { diversity. Negative } \\
\text { edge effect. Effect } \\
\text { of distance on } \\
\text { similarity between } \\
\text { fragments. }\end{array}$ & $\begin{array}{l}83(\mathbf{1 0 0}) \\
83(\mathbf{1 0 0})\end{array}$ & $\begin{array}{l}\text { Nemésio and } \\
\text { Silveira } 2010\end{array}$ \\
\hline $\begin{array}{l}\text { TDO RF } \\
\text { and SF } \\
5-40 \%\end{array}$ & $\begin{array}{l}\text { Few } \\
2-18 \mathrm{ha} \\
1.0-5.0 \mathrm{~km}\end{array}$ & $\begin{array}{l}\text { Mixed matrices } \\
\text { (pastures, } \\
\text { sugarcane, } \\
\text { urban area, } \\
\text { etc.). } \\
\text { NO }\end{array}$ & $\begin{array}{l}\text { No effect of fragment } \\
\text { size on species } \\
\text { richness and } \\
\text { abundance }\end{array}$ & $\begin{array}{l}100(\mathbf{1 0 0}) \\
100(\mathbf{1 0 0}) \\
86(\mathbf{1 0 0})\end{array}$ & $\begin{array}{l}\text { Aguiar and } \\
\text { Gaglianone } 2012\end{array}$ \\
\hline $\begin{array}{l}\text { BARF } \\
>40<50 \%\end{array}$ & $\begin{array}{l}\text { Several } \\
5-625 \mathrm{ha} \\
1.5-3.6 \mathrm{~km}\end{array}$ & $\begin{array}{l}\text { Rubber agro- } \\
\text { forest } \\
\text { YES }\end{array}$ & $\begin{array}{l}\text { High occupation of } \\
\text { agro-forested matrix. } \\
\text { Effect of fragment } \\
\text { size on species } \\
\text { composition and } \\
\text { abundance of some } \\
\text { few common }\end{array}$ & $70(\mathbf{1 0 0})$ & This study \\
\hline
\end{tabular}


Table V. (continued).

\begin{tabular}{|c|c|c|c|c|c|}
\hline $\begin{array}{l}\text { Tropical } \\
\text { forest type } \\
\text { and cover }\end{array}$ & $\begin{array}{l}\text { Fragment } \\
\text { numbers }{ }^{b} \text {, size } \\
\text { and distances }\end{array}$ & $\begin{array}{l}\text { Matrix type and } \\
\text { sampling }\end{array}$ & $\begin{array}{l}\text { Fragmentation } \\
\text { effects }\end{array}$ & $\% \mathrm{SppNAF}^{\mathrm{e}}$ & References $^{\mathrm{f}}$ \\
\hline $\begin{array}{l}\text { BARF } \\
\text { n.a. }\end{array}$ & $\begin{array}{l}\text { Few } \\
21-145 \text { ha } \\
2 \mathrm{~km}\end{array}$ & $\begin{array}{l}\text { Pastures } \\
\mathrm{NO}\end{array}$ & $\begin{array}{l}\text { species. No effect of } \\
\text { fragment size on } \\
\text { total abundance. } \\
\text { Effect of fragment } \\
\text { size on abundance. }\end{array}$ & $83(\mathbf{1 0 0})$ & Ramalho et al. 2009 \\
\hline $\begin{array}{l}\mathrm{RF} \\
\quad>80 \%\end{array}$ & $\begin{array}{l}\text { Few } \\
1-100 \text { ha } \\
0.2-1.0 \mathrm{~km}\end{array}$ & $\begin{array}{l}\text { Secondary } \\
\text { growth } \\
\text { vegetation } \\
\mathrm{NO}\end{array}$ & $\begin{array}{l}\text { Effect of fragment } \\
\text { size on abundance }\end{array}$ & n.a. & $\begin{array}{l}\text { Powell and Powell } \\
1987\end{array}$ \\
\hline $\begin{array}{l}\mathrm{RF} \\
\quad>80 \%\end{array}$ & $\begin{array}{l}\text { Few } \\
\qquad 1-100 \text { ha } \\
0.2-2.8 \mathrm{~km}\end{array}$ & $\begin{array}{l}\text { Secondary } \\
\text { growth } \\
\text { vegetation } \\
\text { NO }\end{array}$ & $\begin{array}{l}\text { No effect of fragment } \\
\text { size on abundance } \\
\text { and species richness } \\
\text { Differential use of } \\
\text { fragments by } \\
\text { different species } \\
\text { subsets }\end{array}$ & $69(\mathbf{1 0 0})$ & Becker et al. 1991 \\
\hline
\end{tabular}

$R F$ rainforest, $S F$ semi-deciduous forest, $D F$ deciduous forest, n.a. information not available

${ }^{a}$ Percentage of the remnant forest covers within a mosaic are rough estimates based on available data in the literature

${ }^{\mathrm{b}}$ Total numbers of forest fragments in the mosaics: few $(\leq 4)$, several $(5-10)$, many $(>10)$

${ }^{\mathrm{c}}$ The distances refer to the distances between nearest forest fragments in each mosaic

${ }^{d}$ The major fragmentation effects describe predominant responses of orchid bees, in spite of the fact that some species may show unique responses to fragmentation processes. Reduced mobility ${ }^{\mathrm{d}}=$ small proportions of marked individuals were recaptured in forest fragments (after flying through the matrix) or exceptionally in the matrix. n.a. information not available

${ }^{\mathrm{e}}$ Species not affected by fragmentation (SppNF): total (italics), and excluding rare species in the samples (boldface in parenthesis). A species was assumed not to be affected by forest fragmentation if it was present in $\geq 50 \%$ of the forest fragments in the same mosaic, and different values in the same study refer to different mosaics. Rare species in the samples were defined as those that were collected in lower numbers than the total number of fragments in a mosaic, or below $1 \%$ of the total sampled individuals. In this study ${ }^{\mathrm{e}}$ with many forest fragments $(N=22)$ and a relative small sample size $(N=412)$, the highest number of fragments occupied $(N=19)$ by the most abundant species was adopted as the "functional number of fragments in the mosaic" (not the actual number of fragments sampled by the author)

${ }^{\mathrm{f}}$ The references only include studies with Euglossini bees that allow to inferring the effects of forest fragmentation

should infer that they were suffering some isolating effect of the rubber tree groves (mobility reduction) within the ARRF mosaic. Unfortunately, it was not possible to differentiate between the effects of isolation and habitat quality on species abundance in small fragments using the current data (e.g., without markrecapture samples).

If matrix quality per se was important, however, spatial-temporal variations in abundance and species composition of orchid bees within the ARRF mosaic would be expected in response to seasonal leaf fall in the rubber tree groves. Although spatial heterogeneity involves approximately $30 \%$ of the total ARRF mosaic area during about 3 months (mid-June to midSeptember), it did not influence the responses of most Euglossini species as expected. For instance, relatively large species and/or those without specialized thermal regulation mechanisms probably might avoid long flights above the forest canopy or exposed to direct sunlight (Roubik 1993; Borrell and Medeiros 2004). This weak response to temporal variations in 
the rubber matrix may be explained by the quality of matrix not being relevant to orchid bees, or to the fact that the distances between the forest fragments in the local mosaic ( $\cong 1-$ $3 \mathrm{~km}$ ) were relatively small in terms of the flight capabilities of orchid bees (i.e., the local mosaic is in a pre-threshold phase of fragmentation), or a combination of both factors.

By comparing results of previous studies (Table V), one should infer a poor relationship between species affected by fragmentation (e.g., 1 -sppNF) and levels of forest fragmentation (from 5 to $90 \%$ of forest cover in the studied mosaics). Particularly the weak influence of different matrices on the occupation of forest fragments contrasted to the general expectations: forest dwellers should occupy with more efficiency arboreal matrices (e.g., Gascon et al. 1999). Together, both tendencies supported the hypothesis that the orchid bees respond only to high thresholds of forest fragmentation (e.g., losses of more than $90 \%$ forest cover), as would be expected of organisms with welldeveloped dispersal capabilities (Andrén 1994; With and Crist 1995) and more specifically with the ability to cover long flight distances (e.g., Janzen 1971; Williams and Dodson 1972) with high metabolic efficiency (e.g., Dudley 1995).

In a pre-threshold phase of fragmentation, the occupation of matrices by many common orchid bees probably produces a dynamic "buffer state" in the small fragments that often reduces distance effects and dissimilarities between forested patches within a mosaic (e.g., sppNF in Table V). Meanwhile, differential use of habitat patches with variable qualities (e.g., Wiens 1976; Pulliam and Danielson 1991) would probably be sufficient to explain most of the observed spatial variations of common orchid bees at previously studied mosaics. The major impacts of fragmentation depend on how the altered matrices act on ecological factors that directly affect bee spatial distributions, principally the availability of floral resources (e.g., Roulston and Goodell 2011) and, in the case of male Euglossini, the spatial availability of odor essences. Orchid epiphytes are key odor sources for Euglossini (e.g., Dodson et al. 1969;
Dressler 1982; Ackerman 1983; Roubik and Hanson 2004), and their seeds can readily disperse from forest patches into agricultural matrices, with varied recruitment success. Moorhead et al. (2010) observed that orchid richness was greater in forests than in monoculture coffee areas (the latter probably representing sink habitats for forest epiphytes), but orchid richness was similar among forest and complex coffee poly-cultures in the same landscape. A preliminary inventory in the ARRF mosaic detected 26 epiphytic orchid species (19 genera) in forest sites and 5 species (four genera) in rubber tree groves, including Catasetum purum (S.H.N. Monteiro, personal communication).

Quality variation among habitat patches in terms of floral odors could be inferred by measuring the spatial variation of orchids' pollinaria attached to the male bees at the mosaic scale. If this is a reasonable premise (see Section 2), the differential quality of rubber tree groves was actually perceived by some orchid bees such as E. cordata and E. ignita. Those bees are abundant species with uniform spatial distributions among LE and very contrasting spatial relationships with orchid flowers at the scale of the ARRF mosaic. It is noteworthy that most specimens of $E$. ignita that carried Catasetum pollinaria were foraging in the rubber tree groves (60\%), while $E$. cordata rarely visited this orchid genus therein. This latter orchid bee is a habitat generalist (e.g., Peruquetti et al. 1999; Viana et al. 2002; Neves and Viana 2003; Farias et al. 2008; Silva et al. 2009; Aguiar and Gaglianone 2012) that searched odors mainly on flowers of Gongora and Coryanthes in forest habitats and in rubber tree groves, respectively. This matrix is effectively used by the both orchid bees, although it is very distinct in terms of availability of odor sources from the point of view of each species.

The contrasting positive or negative edge effects (Nemésio and Silveira 2006, 2010; Brosi 2009; Table V) likely reflect different moments of the spatiotemporal dynamics of the local mosaics and variable susceptibility of local species to biotic pressures caused by deforestation and species-specific variable ability to use 
the matrices. If the rubber tree groves are used mainly by a subset of local species pool, such as E. nigrita and E. ignita, increased fragmentation would favor their expansion in the ARRF mosaic even at a pre-threshold phase. Those favored species will, in turn, affect the populations of species with higher fidelity to forest habitats through edge effects and/or mass effects. When the affected species have large local populations, such as E. imperialis and $E$. atleticana, the initial effects might be detected as population reductions in those mosaic elements more exposed to pressure (rubber plantation and small fragments) by the favored species. When the affected species have small populations because of their specializations, they could quickly disappear from smaller forest fragments, although persisting in the scale of the mosaic, such as E. sapphirina and E. cingulata.

An incipient process of density compensation (sensu MacArthur et al. 1972) is likely underway on the scale of the ARRF mosaic with the disappearance or reduction in abundance of some species in small forest fragments or in rubber tree grove, respectively, that tend to be offset by a subset of common species. In this latter subset, E. nigrita and E. ignita are benefiting from the current level of fragmentation, with high abundances in all LE. E. nigrita is a habitat generalist often associated with open and disturbed habitats (e.g., Peruquetti et al. 1999; Viana et al. 2002; Neves and Viana 2003; Farias et al. 2008; Silva et al. 2009; Justino and Augusto 2010; Aguiar and Gaglianone 2012) whose high abundance in the largest patches of primary forest can be better explained by mass effects (sensu Cody 1989) originating in small fragments of disturbed forest where it has very high densities. It is also very likely that E. ignita is directly benefiting from the availability of the odor resources of Catasetum flowers that are common in the rubber matrix.

Concerning the distances between forest fragments, the ability of Euglossini males to undertake long-distance flights in search of resources within the same forested habitat (Williams and Dodson 1972; Kroodsma 1975; Dressler 1982; Ackerman and Montalvo 1985) should not be translated into a similar disposition to cross very extensive low-quality matrices or disturbed open habitats in the forest surroundings. Very long flights back to natal habitat (or site of capture) can be induced (Janzen 1971), and spontaneous flights of few kilometers $(2-6 \mathrm{~km})$ are probably common through disturbed and non-forested matrices (e.g., Raw 1989; Tonhasca et al. 2003). However, flights of forest dwellers through nonforest matrices would be expected to become shorter when nearest forest fragments are very distant in a landscape (e.g., Milet-Pinheiro and Schlindwein 2005). The differences between reported results by Powell and Powell (1987) and by Becker et al. (1991) in the same experimentally fragmented landscape at Amazon forest (Table VI) also indicate that flights between nearby fragments $(<400 \mathrm{~m})$ may be very limited immediately after deforestation and isolation, although the mobility tends to be reestablished over time as the orchid bees learn the new landscape context. Brosi (2009) also detected significant effects of landscape context on orchid bee abundance within just $400 \mathrm{~m}$ radius around the forest fragments. The effects of fragment size on species composition and on the abundances of some common species in the ARRF mosaic support the argument that at least some species are responding to isolation effects (see above) over distances ranging from 1.5 to $3.6 \mathrm{~km}$.

Long flights through open matrices might depend on directional stimuli (e.g., odors) perceived directly by a male; for this reason, when the resources (stimuli) cannot be detected within its home range, the male would make exploratory flights mainly in the proximity of their forest fragments which should explain the short flights through the very extensive sugarcane matrix observed by Milet-Pinheiro and Schlindwein (2005), for instance. Such behavioral response dependence on landscape context has been documented with damselflies that inhabit forest streams but readily move through pastures to reach nearby forest fragments; however, when forest cover is almost completely removed from the landscape, they are 
unlikely to enter a pasture (Taylor et al. 2006). Risk can be a major selective force on animal behavior (Dall 2010) and using of long distance information (such as odors) may be a key ability of Euglossini to reducing uncertainty and risk associated with foraging and searching suitable habitat patches, in a fragmented landscape.

In summary, there are no apparent differential effects of matrices types on the response of Euglossini to forest fragmentation. It was expected the differential use of matrices according to their distinct structures (arboreal and nonarboreal, e.g.), taking into account potential effects on the spatial distribution and availability of epiphytic orchids, for instance. Probably, this influence has being masked by high mobility, so the comparative approach between mosaics is needed to understand direct (use) and indirect (mobility) effects of the matrices types on orchid bees. Most orchid bees probably respond to very high thresholds of fragmentation, and they were not influenced by the level of fragmentation of studied mosaics (Table V), although the changes in relative area of habitat types were triggering changes in spatial dynamics of some populations, and by extension are affecting the stability of communities at mosaic scale. In this respect, some "rarely sampled species" have persisted only in the largest forest fragments, so with best relative quality, within ARRF mosaic. The spreading of some favored species by the fragmentation, as detected in ARRF mosaic, must have contributed to disappearance of some species with small local populations from the smaller forest fragments. To better understand how the Euglossini bees respond to the fragmentation, it is necessary to go forward with analyses of mechanisms and processes underlying the spatial distribution, in the scale of mosaics.

\section{ACKNOWLEDGMENTS}

We are grateful to Michelin for logistic support and CNPq (Process numbers 481113/2004-5, 478271/2008, and 474313/2011-5) and FAPESB (APR0114/2006) for financial support. We thank the ECOPOL team at UFBA for the help with fieldwork.
We also thank the generous and careful criticism of two anonymous referees.

Distribution spatiale des abeilles à orchidée dans une mosaïque agro-forestière (forêt tropicale humide / plantations d'hévéas): utilisation de l'habitat ou connectivité.

Qualité de l'habitat / niveau de morcellement / paysage / Euglossini

Die räumliche Verbreitung von Prachtbienen in einem Regenwald / Gummigewinnungs-Nutzwaldmosaik: Habitatnutzung oder Vernetzung

Habitatsqualität / Landschaftskontext / Matrixnutzung

\section{REFERENCES}

Ackerman, J. D. (1983) Specificity and mutual dependency of the orchid Euglossine bee interaction. Biol. J. Linn. Soc. 20, 301-314

Ackerman, J. D. (1989) Geographic and seasonal variation in fragrance choices and preferences of male euglossine bees. Biotropica 21, 340-347

Ackerman, J. D. and Montalvo, A. M. (1985) Longevity of euglossine bees. Biotropica 17, 79-81

Ackerman, J. D., Mesler, M. R., Lu, K. L. and Montalvo, A. M. (1982). Food-foraging behavior of male Euglossini (Hymenoptera: Apidae): Vagabonds or Trapliners? Biotropica 14 (4), 241-248

Aguiar, W. M. and Gaglianone, M. C. (2012) Euglossine bees communities in small forest fragments of the Atlantic Forest in southeastern Brazil. Rev. Bras. Entomol. 56, 1-10

Anderson, M. J. (2001) A new method for nonparametric multivariate analysis of variance. Austral Ecol. 26, 32-46

Anderson, M. J. (2005) PERMANOVA: a FORTRAN computer program for permutational multivariate analysis of variance. Department of Statistics, University of Auckland, New Zealand

Andrade-Silva A. C. R., Nemésio, A., Oliveira, F. F., Nascimento, F. S. (2012) Spatial-Temporal Variation in Orchid Bee Communities (Hymenoptera: Apidae) in Remnants of Arboreal Caatinga in the Chapada Diamantina Region, State of Bahia, Brazil. Neotrop. Entomol. 41 (4), 296-305.

Andrén, H. (1994) Effects of habitat fragmentation on birds and mammals in landscapes with different proportions of suitable habitat: a review. Oikos 71, 355-366 
Armbruster, W. S. (1993) Within-habitat heterogeneity in baiting samples of male euglossine bees: possible causes and implications. Biotropica 25, 122-128

Bascompte, J. and Solé, R. V. (1996) Habitat Fragmentation and Extinction Thresholds in spatialy explicit models. J. Anim. Ecol. 65, 465

Becker, P., Moure J. S. And Peralta, F. J. A. (1991) More about euglossine bees in Amazonian forest fragments. Biotropica 23, 586-591

Bezerra, C. P. And Martins, C. F. (2001) Diversidade de Euglossinae (Hymenoptera, Apidae) em dois fragmentos de Mata Atlântica localizados na região urbana de João Pessoa, Paraíba, Brasil. ver. Bras. Zool. 18, 823-835

Borrell, B. J. and Medeiros, M. J. (2004) Thermal stability and muscle efficiency in hovering orchid bees (Apidae: Euglossini). J. exp. Biol. 207, 2925-2933

Brosi, B. J. (2009) The effects of forest fragmentation on euglossine bee communities (Hymenoptera: Apidae: euglossine). Biol. Conserv. 142, 414-423

Brown, J.H. (1995) Macroecology. University of Chicago Press, Chicago, USA

Chesson, P. (2000) Mechanisms of maintenance of species diversity. Annu. Rev. Ecol. Syst. 31 (20), 343-366

Cody, M. L. (1989) Discussion: Structure and Assembly of Communities. In : Roughgarden J., May, R.M. and Levin, S.A. (Eds), Perspectives in ecological theory. Princeton Univ. Press. New Jersey, USA, pp. 227-241

Dall, S. R. X. (2010) Managing risk: the perils of uncertainty. In: Weastneat, D. E. and Fox, C. W. (Eds), Evolutionary behavioral ecology. New York, Oxford Univ. Press. pp. 194-206

Darrault, R. O., Medeiros, P. C. R., Locatelli, E., Lopes, A. V., Machado, I. C., Schlindwein, C. (2006) Abelhas euglossine. In: Diversidade biológica e conservação da floresta Atlântica ao norte do Rio São Francisco (Pôrto, K.C.; Almeida-Cortêz, J.S. and Tabarelli, M. org.). MMA, Brasília. pp. 238-253

Dodson, C. H., Dressler, R. L., Hills, H. G., Adams, R. M., Williams, N. H. (1969) Biologically active compounds in orchid fragrances. Science 164, 1243-1249

Dressler, R. L. (1982) Biology of the orchid bees (Euglossine). Annu. Rev. Ecol. Syst.. 13, 373-394

Dudley, R. (1995) Extraordinary flight performance of orchid bees (Apidae: Euglossini) hovering in heliox (80\% He/20\% O2). J. exp. Biol. 198, 1065-1070

Eltz, T., Roubik, D.W., Lunau, K. (2005) Experiencedependent choices ensure species-specific fragrance accumulation in male orchid bees. Behav Ecol Sociobiol. 59, 149-156

Farias, R. C. A. P., Madeira-da-Silva, M. C., PereiraPeixoto, M. H., Martins, C. F. (2008) Composição e sazonalidade de espécies de Euglossina (Hymenoptera, Apidae) em mata e duna na área de proteção ambiental da Barra do Rio Mamanguape, Rio Tinto, PB. Neotrop. Entomol. 37, 253-258
Faria, L.R. R. and Melo, G.A.R. (2007) Species of Euglossa (Glossura) in the Brazilian Atlantic forest, with taxonomic notes on Euglossa stellfeldi Moure (Hymenoptera, Apidae, Euglossina). Rev. Bras. Entomol. 51, 275-284

Fahrig, L. (2001) How much habitat is enough? Biol. Conserv. 100, 65-74

Flesher, K. M. (2006) The biogeography of the medium and large mammals in a human dominated landscape in the Atlantic Forest of Bahia, Brazil: evidence for the role of agroforestry systems as wildlife habitat. Program in Ecology and Evolution. School-New Brunswick Rutgers, The State University of New Jersey.

Gascon, C., Lovejoy, T. E. Jr., Malcom, R. O. B., Stouffer, J. R., Vasconcelos, P. C., Laurence, H. L., Zimmerman, B. W. F., Tocher, M., Borges, S. (1999) Matrix habitat and species richness in tropical forest remnants. Biol. Conserv. 91, 223-230

Hanski, I., Kouki, J., Halkka, A. (1993) Three explanations of the positive relationship between distribution and abundance of species. In : R. E. Ricklefs and D. Schluter (Eds), Species diversity in ecological communities. University of Chicago Press, Chicago, IL, pp. 108-16

Hanski, I. (1999) Metapopulation ecology. Oxford University Press, Oxford, United Kingdom

Holt, R. D. (1993) Ecology at the mesoscale: the influence of regional processes on local communities. In: Ricklefs, R. and Schluter, D. (Eds), Species Diversity in Ecological Communities. University of Chicago Press, Chicago, IL, pp. 77-88.

Janzen D. H. (1971) Euglossine bees as long distance pollinators of tropical plants. Science 171, 203-205

Justino, D. G., Augusto, S. C. (2010) Avaliação da eficiência de coleta utilizando armadilhas aromáticas e riqueza de Euglossini (Hymenoptera, Apidae) em áreas de Cerrado do Triângulo Mineiro. Rev. Bras. Zoo. 12, 227-239

Kroodsma, D. E. (1975) Flight distances of male euglossine bees in orchid pollination. Biotropica 7 (1), 71-72

Kuussaari, M., Saccheri, I., Camara, M., Hanski, I. (1998) Allee effect and population dynamics in the Glanville fritillary butterfly. Oikos 82, 384-392.

MacArthur, R. H., Diamond, J. M. and Karr, J. R. (1972) Density compensation in island faunas. Ecology 53, 330-342

Mattozo, V. C., Faria, L. R. R., Melo, G. A. R. (2011) Orchid bees (Hymenoptera: Apidae) in the coastal forests of southern Brazil: diversity, efficiency of sampling methods and comparison with other Atlantic forest surveys. Papéis Avulsos de Zoologia 51, 505-515

Mccune, B., Grace, J. B. (2002) Analysis of Ecological communities. Oregon: MjM Software Design

Melo, P. M., Gimenes, M., Oliveira-Neto, A. (2009) Daily activity patterns of visits by males of four 
species of Eulaema (Apidea: Euglossini) to odor baits in a tropical forest fragment in Bahia. Bras. Zool. 26, 204-212

Michelin (2011) Histórico. Acesso em 22/04/2011. http:// www.michelin-hevea.com/hevea/front/affich.jsp? codeRubrique $=28102004110947026$ andlang $=$ PT.

Milet-Pinheiro, P. ,Schlindwein, C. (2005) Do euglossine males (Apidae, euglossine) leave tropical rainforest to collect fragrances in sugarcane monocultures! Rev. Bras. Zoo. 22 (4), 853-858

Moorhead, L. C., Philpott, S. M. and Bichier, P. (2010) Epiphyte biodiversity in the coffee agricultural matrix: canopy stratification and distance from forest fragments. Conserv. Biol. 24, 737-746

Nemésio, A., Silveira, F. A. (2006) Edge effects on the orchid bee fauna (Hymenoptera: Apidae: Apini: Euglossina) at a large remnant of Atlantic Rain Forest in southeastern Brazil. Neotrop. Entomol. 35, 313-323

Nemésio, A., Silveira, F. A. (2010) Forest fragments with larger core areas better sustain diverse orchid bee faunas (Hymenoptera: Apidae: Euglossina). Neotrop. Entomol. 39, 555-561.

Neves, E. L., B. F. Viana. (2003) A fauna de abelhas da subtribo Euglossina (Hymenoptera, Apidae) do Estado da Bahia, Brasil, In: G.A.R. Melo and I.A. Santos (Eds). Apoidea Neotropica: Homenagem aos 90 anos de Jesus Santiago Moure. Criciúma, UNESC. pp. 223-229

Pereira J. P., Doretto, M., Leal, A. C., Castro, A. M. G. , Rucker, N. A. (1996) Cadeia produtiva da borracha natural: análise diagnóstica e demandas atuais no Paraná. Ed. Iapar, Londrina-PR

Peruquetti, R. C., Campos, L. A. O., Coelho, C. D. P., Abrantes, C. V. M., Lisboa, L. C. O. (1999) Abelhas euglossine (Apidae) de áreas de Mata Atlântica: abundância, riqueza e aspectos biológicos. Rev. Bras. Zool. 16 ( 2), 101-118

Por, F. D. (1992) Sooretama. The Atlantic Rain Forest of Brazil. SPB Academic Publish. The Hague, The Netherlands

Powell, A. H. and Powell, G. V. N. (1987) Population dynamics of male euglossine bees in Amazonian Forest fragments. Biotropica 19, 176-179

Pulliam R. H. (1989) Individual behavior and the procurement of essential resources. In Roughgarden, J. May, R.M., Levin, S.A. (eds). 1989. Perspectives in ecological theory. Princeton University Press, New Jersey. pp. $25-38$

Pulliam, H. R. ,Danielson, B. J. (1991) Sources, sinks, and habitat selection: a landscape perspective on population dynamics. Am. Nat. 137 (Suppl.), S50-S66

Ramalho, A. V., Gaglianone, M. C., .Oliveira, M. L. (2009) Comunidades de abelhas Euglossina (Hymenoptera, Apidae) em fragmentos de Mata Atlântica no Sudeste do Brasil. Rev. Bras. Entomol. 53, 95-101

Ramirez, S., R. L. Dressler ,M. Ospina. (2002) Abejas euglossinas (Hymenoptera: Apidae) de la Región
Neotropical: Listado de especies com notas sobre su biología. Biol. Colomb. 3, 7-118

Raw, A. (1989) The dispersal of euglossine bees between isolated patches of eastern Brazilian wet forest (Hymenoptera, Apidae). Rev. Bras. Entomol. 33, 103-107

Reis, E. L. and Mello, F. A. F. (1987) Efeito da adubação no desenvolvimento da seringueira em formação (Hevea brasiliensis Muell, Arg.) no sul do estado da Bahia.: Anais da E.S.A. "Luiz de Queiroz" 44, $1165-1187$

Roubik, D. W. (1993) Tropical pollinators in the canopy and understory: field data and theory for stratum "preferences." J. Ins. Behav. 6, 659-673

Roubik, D. W. (2001) Ups and downs in pollinator populations: when is there a decline? Conserv. Ecol. 5, article 2. See http://www.consecol.org/vol5/iss1/art2.

Roubik, D. W. ,Hanson, P. E. (2004) Orchids bees: biology and field guide. San Jose, Costa Rica, INBIO

Rosa, J. F., Oliveira, J. P. L., Gurgel, Z. E. R., Duarte, C. S. A.; Ramalho, M. (2008) Estratificação da atividade de coleta de essência por abelhas Euglossina, em um remanescente de Mata Atlântica na Reserva da Michelin, Bahia, Brasil. Sitientibus. 8, 307-310

Roulston T. H., Goodell K. (2011) The role of resources and risks in regulating wild bee populations. Annu. Rev. Entomol. 56, 293-312

Silva, O., Rêgo, M. M. C., Albuquerque, P. M. C., Ramos, M. C. (2009) Abelhas euglossina (Hymenoptera, Apidae) em área de restinga do Nordeste do Maranhão, Brasil. Neotro. Entomol. 38, 186-196

Silveira, F. A., Melo, G. A. R. and Almeida, E. A. B. (2002) Abelhas Brasileiras: Sistemática e Identificação. Belo Horizonte, Edição do autor.

Schowalter, T. D. (2006) Insect Ecology: An Ecosystem Approach, 2nd edn. Elsevier, Burlington, USA

Summerville, K. S., and Crist, T. O. (2001) Effects of experimental habitat fragmentation on patch use by butterflies and skippers (Lepidoptera). Ecology 82, $1360-1370$

Sutherland, W. J. (ed.) (2006) Ecological Census Techniques. 2a. ed. Cambridge Univ. Press

Taylor, P., Fahrig, L. And With, K. A. (2006) Landscape connectivity: a return to the basics. In: Krooks and Sanjayan, (Eds.). Connectivity Conservation (Cambridge University Press, Cambridge, UK. pp. 44-71

Tonhasca, A., Blackmer, J. L., Albuquerque, G. S. (2002) Within habitat heterogeneity of Euglossine bee populations: a reevaluation of the evidence. $\mathrm{J}$. Trop. Ecol. 18, 929-933

Tonhasca, J. R., Albuquerque, A. G. S., Blackmer, J. L. (2003) Dispersal of euglossine bees between fragments of the brazilian Atlantic Forest. J. Trop. Ecol. 19, 990-102

Turner, M. G., Gardner, R. H. , O'Neill, R. V. (2003) Landscape ecology in theory and practice. Springer Verlag, New York. 
Veloso, H. P.; Rangel Filho, A. L. and Lima, J. C. A. (1991) Classificação da vegetação brasileira, adaptada a um sistema universal. IBGE, Rio de Janeiro.

Viana, B.F., A. M. P. Kleinert and E. L. das Neves. (2002) Comunidade de Euglossini (Hymenoptera, Apidae) das dunas litorâneas do Abaeté, Salvador, Bahia, Brasil. Rev. Bras. Entomol. 46, 539545

Wiens, J. A. (1976) Population responses to patchy environments. Annu. Rev. Ecol. Syst. 7, 81-120

Williams, N. H. And Whitten, W. M. (1983) Orchid floral fragances and male euglossine bees: methods and advances in last sesquidecade. Biol. Bull. 164, 355-395

Williams, N. H., Dodson, C. H. (1972) Selective attraction of male euglossine bees to orchid floral fragrances and its importance in long distance pollen flow. Evolution 26, 84-95

Williams N. M., Thomson J. D. (1998) Trapline foraging by bumble bees. III. Temporal patterns of visitation and foraging success at single plants. Behav. Ecol. 9, 612-621

With, K. A. And Crist, T. O. (1995) Critical thresholds in species responses to landscape structure. Ecology 76, 2446-2459 